\section{Substrate Type and Salinity Affect Growth Allocation, Tissue Ion Concentrations, and Physiological Responses of Carrizo Citrange Seedlings}

\author{
Francisco García-Sánchez \\ Centro de Edafología y Biología Aplicada del Segura, CSIC, Campus \\ Universitario de Espinardo, Espinardo, Murcia, Spain
}

\author{
James P. Syvertsen ${ }^{\mathbf{1}}$ \\ University of Florida, IFAS, Citrus Research and Education Center, 700 \\ Experiment Station Road, Lake Alfred, FL 33850
}

Additional index words. citrus, rootstock, salt tolerance, mineral nutrition, leaf water relations, net gas exchange

\begin{abstract}
To gain insight into salinity tolerance of citrus, we studied growth, leaf, and root $\mathrm{Cl}^{-}$concentrations and physiological responses of 5-month-old seedlings of the citrus rootstock Carrizo citrange [Citrus sinensis $(\mathrm{L}$.$) Osb. \times$ Poncirus trifoliate $\mathrm{L}$.] grown in a greenhouse in three different substrates: Candler sand soil, Floridana sandy clay soil, or a commercial soilless peat/perlite/vermiculite potting media. Plants were kept wellwatered with a complete nutrient solution plus either no salt (control) or $50 \mathrm{mM} \mathrm{NaCl}$ for 9 weeks. Without salinity, substrate type did not affect total plant growth although there were differences in shoot/root dry weight ratio and mineral nutrient relationships attributable to substrate. Predawn leaf water potential, midday $\mathrm{CO}_{2}$ assimilation, and leaf water use efficiency were highest in seedlings grown in the soilless peat. The salt treatment decreased leaf and root growth, reduced leaf $\mathrm{Ca}^{2+}$, and increased leaf $\mathrm{K}^{+}$ concentration in all the three substrates. Overall, plant growth was negatively related to leaf $\mathrm{Cl}^{-}$. Leaf growth reductions were least in Candler-grown seedlings and greatest in Floridana soil as $\mathrm{Cl}^{-}$concentrations were lowest in Candler sand and highest in Floridana soil. Leaf $\mathrm{Na}^{+}$was also highest in Floridana seedlings. In contrast to salt ions in leaves, roots of salinized seedlings in Candler sand had the highest $\mathrm{Na}^{+}$and $\mathrm{Cl}^{-}$concentration. Salinity reduced net gas exchange of leaves similarly in all three substrates. Salinity reduced both leaf water potential and osmotic potential such that leaf turgor was increased. Thus, salinity-induced reductions in growth and net gas exchange were not the result of loss of turgor but more likely resulting from toxic ion accumulation in leaves. Based on the relative rankings of leaf growth and leaf $\mathrm{Cl}^{-}$concentrations, Carrizo seedlings from Candler sand had the highest salt tolerance and those grown in Floridana soil had the lowest salt tolerance. Substrate type should be considered when characterizing plant growth and physiological responses to salinity.
\end{abstract}

Citrus is one of the most important commercial crops in Florida annually generating a U.S. \$9 billion impact with almost U.S. \$1 billion in tax revenues (Hodges et al., 2001). Citrus tree growth and fruit yield are sensitive to salinity stress (García-Sánchez et al., 2006; Grieve et al., 2007; Prior et al., 2007) and despite an abundance of summer rainfall in Florida, salinity can be an important problem in citrus production, especially during the dry

\footnotetext{
Received for publication 21 Apr. 2009. Accepted for publication 24 May 2009.

Funding for this research came from the Ministerio de Educación y Ciencia (Gobierno de España), Project Plan Nacional AGL2007-65437-C04-02/ AGR while F.G.-S. was a visiting scientist in the JS Laboratory.

${ }^{1}$ To whom reprint requests should be addressed; e-mailjmsn@ufl.edu.
}

spring and fall seasons (Syvertsen et al., 1989). In addition, salt stress-related problems are increasing in some coastal areas where salt water intrudes from the ocean (Boman, 2005).

Citrus leaf turgor potential is often higher in salinized than in nonsalinized citrus leaves apparently from the contribution of $\mathrm{Na}^{+}$and and Syvertsen, 2006; Pérez-Pérez et al., 2007). The adverse effects of $\mathrm{NaCl}$ on citrus tree growth have been related primarily to high $\mathrm{Cl}^{-}$in leaves (Bañuls et al., 1997; Romero-Aranda et al., 1998) and secondarily to high leaf $\mathrm{Na}^{+}$(Storey and Walker, (1987). Thus, salinity tolerance can be interpreted as the ability of citrus rootstocks to prevent the accumulation of $\mathrm{Cl}^{-}$in leaves (Levy and Syvertsen, 2004). There is a marked effect of citrus rootstocks on the uptake and transport of $\mathrm{Cl}^{-}$and/or $\mathrm{Na}^{+}$. For example, the rootstock $\mathrm{Cl}^{-}$to osmotic adjustment (García-Sánchez
Cleopatra mandarin has a good capacity to exclude $\mathrm{Cl}^{-}$, whereas Carrizo citrange is considered to be a $\mathrm{Cl}^{-}$accumulator but a good $\mathrm{Na}^{+}$excluder (Bañuls and Primo-Millo, 1995; Levy et al., 1999). The $\mathrm{Cl}^{-}$accumulation mechanism in Carrizo could be linked to its relatively high water use, its more efficient root system for water uptake, and/or to its relatively low shoot-to-root ratio (Moya et al., 2003). Salinity tolerance also can be equated to continued growth and high water use efficiency under salinity stress (GarcíaSánchez and Syvertsen, 2006). High $\mathrm{Cl}^{-}$and/ or $\mathrm{Na}^{+}$concentrations in well-watered citrus leaves reduces net assimilation of $\mathrm{CO}_{2}$ $\left(\mathrm{A}_{\mathrm{CO} 2}\right)$ by a direct biochemical inhibition of photosynthetic capacity rather by decreases in stomatal conductance $\left(g_{\mathrm{s}}\right)$ or leaf water potential (García-Sánchez et al., 2006; Levy and Syvertsen, 2004). Using salinity-induced decreases in leaf photosynthetic responses as an index of salt tolerance, however, can be confusing because $\mathrm{A}_{\mathrm{CO} 2}$ is not always well correlated with plant growth (García-Legaz et al., 1993).

Poor soil drainage and low available water (Pérez-Pérez et al., 2007) can interact with salinity stress and affect the response of crops to salinity. A high concentration of soil $\mathrm{Ca}^{2+}$ improved growth of tomato plants by increasing $\mathrm{Ca}^{2+}$ and $\mathrm{K}^{+}$absorption and restoring cation balance while restricting $\mathrm{Na}^{+}$ absorption in relation to soils with low $\mathrm{Ca}^{2+}$ (Yamada et al., 2007). Soil ion exchange capacity, mechanical impedance of roots, soil texture, and/or the effect of soil matric potential can influence the availability of $\mathrm{Na}^{+}$and $\mathrm{Cl}^{-}$ions and, consequently, influence salinity tolerance (Villagra and Cavagnaro, 2005). For example, Norway spruce seedlings grown in sandy soil had more severe necrosis and significantly higher concentrations of $\mathrm{Na}^{+}$and $\mathrm{Cl}^{-}$than seedlings grown in loam, silt loam, or peat soils because ion concentrations in the soil solution were generally higher in sandy soils (Fostad and Pedersen, 2000). In citrus, salt tolerance was greater in Etrog citron and Rangpur lime seedlings grown in sandy soil than those grown in solution culture because seedlings grown in sandy soil had a greater ability to exclude $\mathrm{Na}^{+}$and $\mathrm{Cl}^{-}$from leaves (Storey, 1995). Thus, plants grown in different substrates can respond differently to the same amount of salinity and these differences can contribute to conflicting interpretations of relative salt tolerance. The objective of this study was to determine the effect of substrate type on the salt tolerance of seedlings of Carrizo citrange, a common citrus rootstock. We determined leaf $\mathrm{Cl}^{-}$and $\mathrm{Na}^{+}$, the ability to maintain plant growth, and physiological function under salinity stress.

We contrasted three substrates: Candler sand soil, Floridana sandy clay soil, and a soilless peat-based potting media. Candler sand is a typical citrus soil in central Florida and contains very little clay or organic matter (He et al., 2000). Floridana is a dark soil typical of some flatwoods or depressional areas, is very poorly drained, and slowly to 
very slowly permeable (Soil Conservation Service, 1990). Florida citrus trees must be grown on raised beds in this soil to allow for sufficient drainage. The soilless peat-based potting media is typically used in nurseries because it has high organic matter content, is well-drained, but has good ability to retain water and nutrients. Therefore, we hypothesized that plants grown in the soilless peat mix would display greater salt tolerance than those grown in the two soil types.

\section{Materials and Methods}

Plant material and growing conditions. This study was carried out at the University of Florida's Citrus Research and Education Center (Lake Alfred, FL; long. $28^{\circ} \mathrm{N}$, lat. $82^{\circ}$ W). Seeds of Carrizo citrange [Citrus sinensis (L.) Osb. $\times$ Poncirus trifoliata L.] were germinated in vermiculite wetted with $0.5 \mathrm{mmol} \cdot \mathrm{L}^{-1} \mathrm{CaSO}_{4}$. When seedlings were 1 month old, uniform plants were transplanted to $0.15-\mathrm{L}$ containers filled with autoclaved native Candler sand, Floridana soil, or the commercial soilless mixture of peat/perlite/ vermiculite at $82.5 / 12.5 / 0.5 \%$ by volume (Pro-Mix, BX; Premier Horticulture Inc., Red Hill, PA). Candler sand is a well-drained, typic quartzipsamment and Floridana soil is a poorly drained loamy Argiaquoll (Li et al., 2006; Soil Conservation Service, 1990). Characteristics of these substrates are summarized in Table 1. Seedlings were grown in a greenhouse under natural photoperiods during the late summer when maximum photosynthetically active radiation (PAR; LI-170; LICOR, Inc., Lincoln, NE) at plant level was $\approx 1500 \mathrm{mmol} \cdot \mathrm{m}^{-2} \cdot \mathrm{s}^{-1}$. Average day/ night temperature was $36 / 21{ }^{\circ} \mathrm{C}$ and relative humidity varied diurnally from $40 \%$ to $100 \%$.

Plants were well-watered and wellnourished by watering every other day with a dilute solution of a complete fertilizer $(8 \mathrm{~N}-$ $0.66 \mathrm{P}-6.64 \mathrm{~K}$ ) plus $6 \%$ iron chelate in a sufficient volume to leach from the bottom of all pots. Plants received $\approx 21 \mathrm{mg}$ of nitrogen per week. Two months after transplanting, either $0 \mathrm{mM}$ (Control) or $50 \mathrm{mM}$ $\mathrm{NaCl}$ (Salt) was added to the nutrient solution. To avoid an osmotic shock, salinity was increased in increments of $10 \mathrm{mM} \mathrm{NaCl}$ per day until $50 \mathrm{mM} \mathrm{NaCl}$ was achieved. The 50 $\mathrm{mM}$ salinity treatments continued for 9 weeks during September to October. The experimental design was a $2 \times 3$ factorial of two salt treatments $(0 \mathrm{mM} \mathrm{NaCl}$ or $50 \mathrm{mM}$ $\mathrm{NaCl}$ ) by three substrates (Candler sand,

Table 1. Moist bulk density (MBD), cation exchange capacity (CEC), percentages of sand, silt, clay, and organic matter (OM), and available water capacity (AWC) of Candler sand, Floridana soil, ${ }^{\mathrm{z}}$ and soilless peat mix.

\begin{tabular}{lcccccccc}
\hline Substrate & $\begin{array}{c}\text { MBD } \\
\left(\mathrm{g} \cdot \mathrm{cm}^{-3}\right)\end{array}$ & $\begin{array}{c}\text { CEC } \\
(\mathrm{meq} / 100 \mathrm{~g})\end{array}$ & $\begin{array}{c}\text { Sand } \\
(\%)\end{array}$ & $\begin{array}{c}\text { Silt } \\
(\%)\end{array}$ & $\begin{array}{c}\text { Clay } \\
(\%)\end{array}$ & $\begin{array}{c}\text { OM } \\
(\%)\end{array}$ & $\begin{array}{c}\text { AWC } \\
(\%)\end{array}$ & $\mathrm{pH}$ \\
\hline Candler & 1.45 & 5 & 97 & 1 & 1 & 1 & 5.5 & 5.2 \\
Floridana & 1.60 & 7 & 54 & 15 & 30 & 1 & 15 & 6.4 \\
Soilless peat & $0.35-0.50^{\mathrm{y}}$ & 58 & - & - & - & 81 & $60-75$ & $5.2-6.2$ \\
\hline
\end{tabular}

${ }^{2} \mathrm{Li}$ et al., 2006; Soil Conservation Service, 1990.

yPro-Mix; Premier Horticulture Inc., Red Hill, PA.

Floridana soil, and soilless peat media) with six replicate plants in each treatment.

Plant water relations. Leaf water relations and all subsequent leaf measurements were done on 5-month-old seedlings using fully expanded mature leaves from the mid stem area of each plant. Near the end of the experiment (October), predawn (0500 to $0600 \mathrm{HR})$ leaf water potential $\left(\Psi_{\mathrm{w}}\right)$ was measured in one leaf for each replicate plant with a pressure chamber (PMS Instrument, Corvallis, OR). After $\Psi_{\mathrm{w}}$, measurement leaves were tightly enclosed in aluminum foil, frozen by immersing in liquid nitrogen, and stored in a freezer at $-18{ }^{\circ} \mathrm{C}$ until analysis. After thawing at $25 \pm 1{ }^{\circ} \mathrm{C}$, leaf $\psi_{\mathrm{S}}\left(\Psi_{\pi}\right)$ was quickly measured in the expressed cell sap collected in a syringe and placed in an osmometer (Digital Osmometer; Wescor, Logan, UT). Leaf pressure potential $\left(\Psi_{\mathrm{P}}\right)$ was calculated as the difference between the $\Psi_{\pi}$ and $\Psi_{\mathrm{w}}$ expressed in MPa. At midday (1100 to $1200 \mathrm{HR}$ ), similar leaves to those leaves used for $\Psi_{\mathrm{w}}$ were harvested and immediately weighed to obtain a leaf fresh weight (f. wt) to measure the relative water content (RWC). Leaves were placed in a beaker with petioles submerged in water overnight in the dark so that leaves could become fully hydrated. Leaves were reweighed to obtain turgid weight (t. wt) and dried at $60{ }^{\circ} \mathrm{C}$ for $48 \mathrm{~h}$ to obtain leaf dry weight $(\mathrm{dr} w \mathrm{w})$. RWC was calculated as $\left[(\mathrm{f}\right.$. wt $\left.-\mathrm{dr} w \mathrm{t}) \times(\mathrm{t} . \mathrm{wt}-\mathrm{dr} \mathrm{wt})^{-1}\right] \times 100$ (Morgan, 1984).

Gas exchange and chlorophyll fluorescence measurements. Near the end of the experiment, net assimilation of $\mathrm{CO}_{2}\left(\mathrm{~A}_{\mathrm{CO} 2}\right)$ and leaf transpiration $\left(\mathrm{E}_{\mathrm{lf}}\right)$ were measured using one similar leaf from each replicate plant using a portable photosynthesis system (LI-6200; LI-COR Inc.) with a 0.25-L cuvette. Photosynthetic water use efficiency $\left(\mathrm{WUE}=\mathrm{A}_{\mathrm{CO} 2} \mathrm{E}_{\mathrm{lf}}^{-1}\right), g_{\mathrm{s}}$, and intercellular $\mathrm{CO}_{2}$ concentration $\left(\mathrm{C}_{\mathrm{i}}\right)$ were calculated by the system. The cuvette was equipped with an external light source (Model QB1205LI-670; Quantum Devices Inc., Barneveld, WI) to maintain a constant $P A R$ of $800 \mathrm{mmol} \cdot \mathrm{m}^{-2} \cdot \mathrm{s}^{-1}$ during measurements, which is sufficient to saturate citrus leaves grown in full sun (Syvertsen, 1984). All measurements were made in the morning from 0800 to $1000 \mathrm{HR}$ to avoid high afternoon temperatures and low humidity. During all measurements, the leaf temperature was $32 \pm 2{ }^{\circ} \mathrm{C}$ and leaf-to-air vapor pressure difference was $2.4 \pm 0.4 \mathrm{kPa}$ within the cuvette.

HortScience Vol. 44(5) August 2009
Leaf chlorophyll $a$ fluorescence was measured with a pulse-modulated fluorometer (Model OS1-Fl; Opti-Sciences, Tyngsboro, MA) using similar leaves on each plant. Fluorescence measurements were made between 0900 and $1000 \mathrm{HR}$ under ambient light and also after 20 min of acclimation to dark under leaf clips (FL-DC; OptiSciences). The maximum quantum efficiency $\left(\mathrm{F}_{\mathrm{v}} / \mathrm{F}_{\mathrm{m}}\right)$ of photosystem II was calculated as $\mathrm{F}_{\mathrm{v}} / \mathrm{F}_{\mathrm{m}}=\left(\mathrm{F}_{\mathrm{m}}-\mathrm{F}_{\mathrm{o}}\right) / \mathrm{F}_{\mathrm{m}}$, in which $\mathrm{F}_{\mathrm{m}}$ and $\mathrm{F}_{\mathrm{o}}$ were maximal and minimal fluorescence of dark-adapted leaves, respectively (Jifon and Syvertsen, 2003; Maxwell and Johnson, 2000). Quantum yield (Y) was measured as $\mathrm{Y}=\left(\mathrm{F}_{\mathrm{m}}^{\prime}-\mathrm{F}\right) / \mathrm{F}_{\mathrm{m}}^{\prime}$ in which $\mathrm{F}_{\mathrm{m}}^{\prime}$ and $\mathrm{F}$ were the maximal and steady-state fluorescence yield in the light, respectively. Light pulse intensity for achievement of $\mathrm{F}^{\prime}{ }_{\mathrm{m}}$ and $\mathrm{F}$ was of $600 \mathrm{~nm}$.

Plant transpiration and leaf area. Two days before the end of the experiment, whole plant transpiration was measured gravimetically. Individual pots were covered with plastic bags sealed at the base of the stem to stop evaporation. Weight loss from each pot was measured during two 6- to 7-h daytime periods on 2 selected clear days. Daily weight loss per pot was averaged for the $2 \mathrm{~d}$. At harvest, total leaf area per plant was destructively measured (LI-3000; LI-COR) and used to calculate $\mathrm{E}_{\text {leaf }}$ in $\mathrm{mol} \cdot \mathrm{m}^{-2} \cdot \mathrm{h}^{-1}$.

Electrical conductivity and $\mathrm{Cl}^{-}$concentration in the drainage solution. Electrical conductivity and $\mathrm{Cl}^{-}$concentrations in the drainage solution leached from each pot were measured at the end of the experiment. The leachate was collected after watering with $20 \mathrm{~mL}$ of distilled water. EC was measured with an Orion EC meter and $\mathrm{Cl}^{-}$concentration in solution was measured using a silver ion titration chloridometer (HBI Chloridometer; Haake Buchler, Saddle Brook, NJ).

Growth and nutrient concentrations. Nine weeks after initiating the salinity treatments, plants were harvested and separated into leaves, stems, and washed roots. Tissues were briefly rinsed with deionized water, oven-dried at $60{ }^{\circ} \mathrm{C}$ for at least $48 \mathrm{~h}$, weighed, and ground to a fine powder. Subsamples of leaf and root tissues were extracted with a $0.1 \mathrm{~N}$ solution of nitric acid and $10 \%$ acetic acid. Tissue chloride concentration was measured with the chloridometer as stated previously. Tissue $\mathrm{Na}^{+}, \mathrm{K}^{+}, \mathrm{Mg}^{2+}, \mathrm{Ca}^{+2}$, and phosphorus concentrations were determined by inductively coupled plasma spectrometry (Iris Intrepid II; Thermo Electron Corporation, Franklin, TN) after previous acid digestion in $\mathrm{HNO}_{3}: \mathrm{H}_{2} \mathrm{O}_{2}(5: 3$ by volume) in a microwave reaching $200{ }^{\circ} \mathrm{C}$ in $20 \mathrm{~min}$ and holding at this temperature for 2 h (CEM Mars Xpress, Matthews, NC). Tissue nitrogen concentration was measured using a Thermo-Finnigan 1112 EA elemental analyzer (Thermo-Finnigan, Milan, Italy). All tissue nutrient concentrations were expressed in units of mmol $\cdot \mathrm{kg}^{-1} \mathrm{dr} \mathrm{wt}$.

Statistical analysis. Data were analyzed using a two-way analysis of variance (SPSS Statistical Package, Chicago, IL) with three substrate and two salinity treatments. When 
the substrate treatments, salinity treatments, or their interactions were significant $(P<$ 0.05), means were separated using Duncan' s multiple range test. Linear regression and Pearson product moment correlation coefficient were used to estimate relationships between selected variables.

\section{Results}

Substrate characteristics. Although Candler sand and Floridana soil differed in percentages of sand, silt, and clay, their moist bulk density (MBD) and cation exchange capacity (CEC) were similar (Table 1). The soilless peat mix had a much lower MBD along with the higher CEC, organic matter, and available water than the soils.

Plant growth. Despite substrate differences in available water content, total plant growth of the nonsalinized control seedlings was unaffected by substrate type because leaf, root ,and total plant dry weight averaged $1.17 \mathrm{~g}, 5.0 \mathrm{~g}$, and $10.5 \mathrm{~g}$, respectively, regardless of substrate (Fig. 1A-C). Growth allocation was affected by substrate, however, because Floridana seedlings had a higher shoot-to-root dr wt ratio (Sh/Rt) than those from soilless peat (Fig. 1D). The salt treatment reduced leaf, root, and total plant growth in plants from all the three substrates. Salinized plants from Candler sand had the highest leaf dry weight and plants from Floridana soil had the lowest leaf dry weight, whereas plants from soilless peat were intermediate. Salinized plants from Floridana soil also had the lowest root and total plant growth. Salinity did not affect $\mathrm{Sh} / \mathrm{Rt}$ ratio in plants from all the three substrates.

Chloride and sodium concentrations in leaves and roots. There were no differences in the relatively low $\mathrm{Cl}^{-}$and $\mathrm{Na}^{+}$concentrations in leaves and roots of plants grown with $0 \mathrm{mM} \mathrm{NaCl}$ (Fig. 2). Salinity increased the concentration of $\mathrm{Cl}^{-}$and $\mathrm{Na}^{+}$in leaves and roots of all seedlings regardless of substrate. Overall, leaf $\mathrm{Cl}^{-}$increased significantly more than leaf $\mathrm{Na}^{+}$as tested by linear regression and a $t$ test of slopes at $P<0.05$ (not shown but see Fig. 2A-B). Overall, leaf growth was negatively related to leaf $\mathrm{Cl}^{-}(P<0.001, r=$ -0.80 ) because seedlings in the Candler sand had the lowest leaf $\mathrm{Cl}^{-}$, whereas seedlings in Floridana soil had the highest leaf $\mathrm{Cl}^{-}$. The highest leaf $\mathrm{Na}^{+}$concentration occurred in seedlings grown in Floridana soil, whereas seedlings grown in Candler sand and soilless peat had similar leaf $\mathrm{Na}^{+}$. The concentration of $\mathrm{Cl}^{-}$and $\mathrm{Na}^{+}$in roots, however, was highest in seedlings from Candler sand, whereas roots from Floridana soil had the lowest $\mathrm{Na}^{+}$concentration (Fig. 2C-D).

Mineral nutrient concentrations. Leaves from seedlings grown in Candler sand had the highest $\mathrm{Ca}^{2+}$, whereas seedlings from soilless peat had the highest leaf $\mathrm{Mg}^{2+}$ concentration (Table 2). Seedlings from Floridana soil had the highest leaf $\mathrm{K}^{+}$concentration and seedlings from Candler sand had a higher leaf phosphorus concentration than those grown in Floridana soil. The salinity treat-

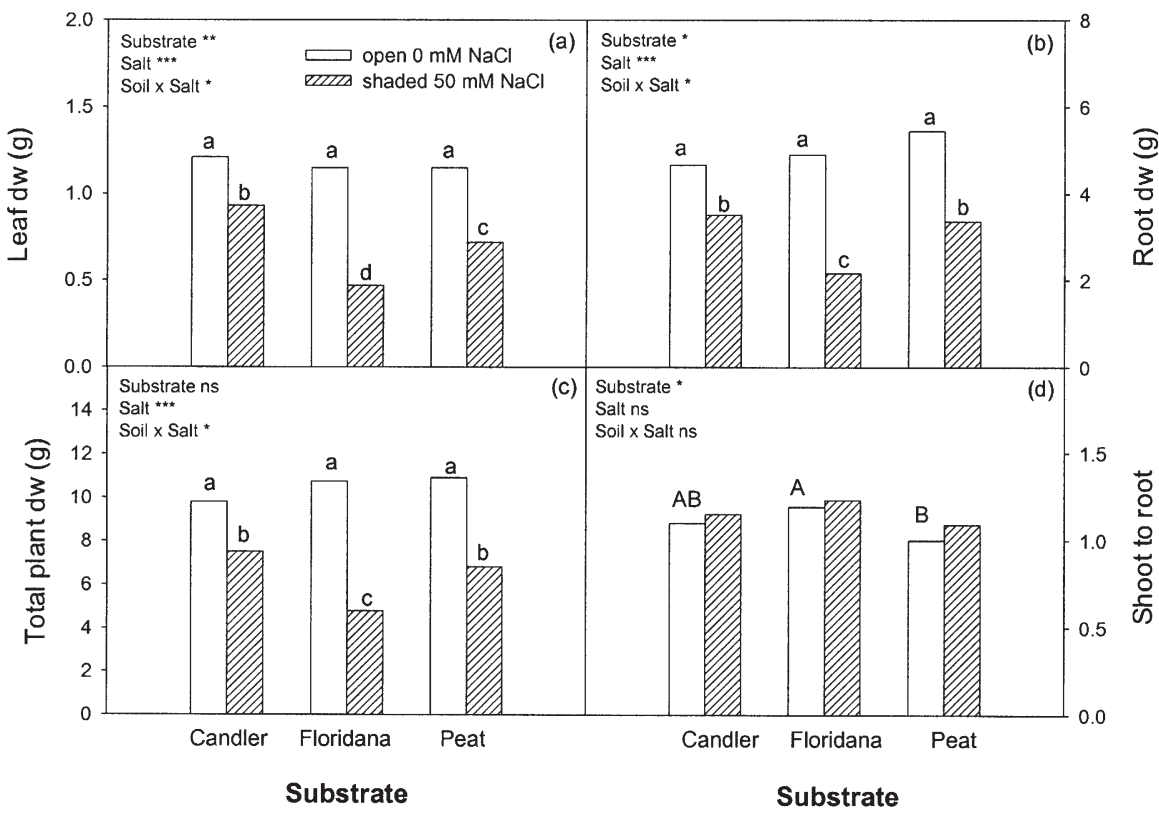

Fig. 1. Effects of growth substrate (Candler sand, Floridana soil, or soilless peat) and salt treatment (control $=0 \mathrm{NaCl}$, open bars or salt $=50 \mathrm{mM} \mathrm{NaCl}$, shaded bars $)$ on mean $(\mathrm{n}=6)$ leaf dry weight $(\mathrm{dw}, \mathbf{A})$, root $\mathrm{dw}(\mathbf{B})$, total plant dw (C), and shoot-to-root dw ratio (Shoot/Root; D) of Carrizo citrange rootstock seedlings. NS, $* * *, * * *$ Nonsignificant or significant differences at $P<0.05,0.01$, or 0.001 , respectively, for the main effects and two-way interaction of substrate $\times$ salt treatments. Different upper case letters within each figure indicate significant differences at $P<0.05$ between substrates; different lower letters within each figure indicate significant differences at $P<0.05$ among substrate $\times$ salt treatments.

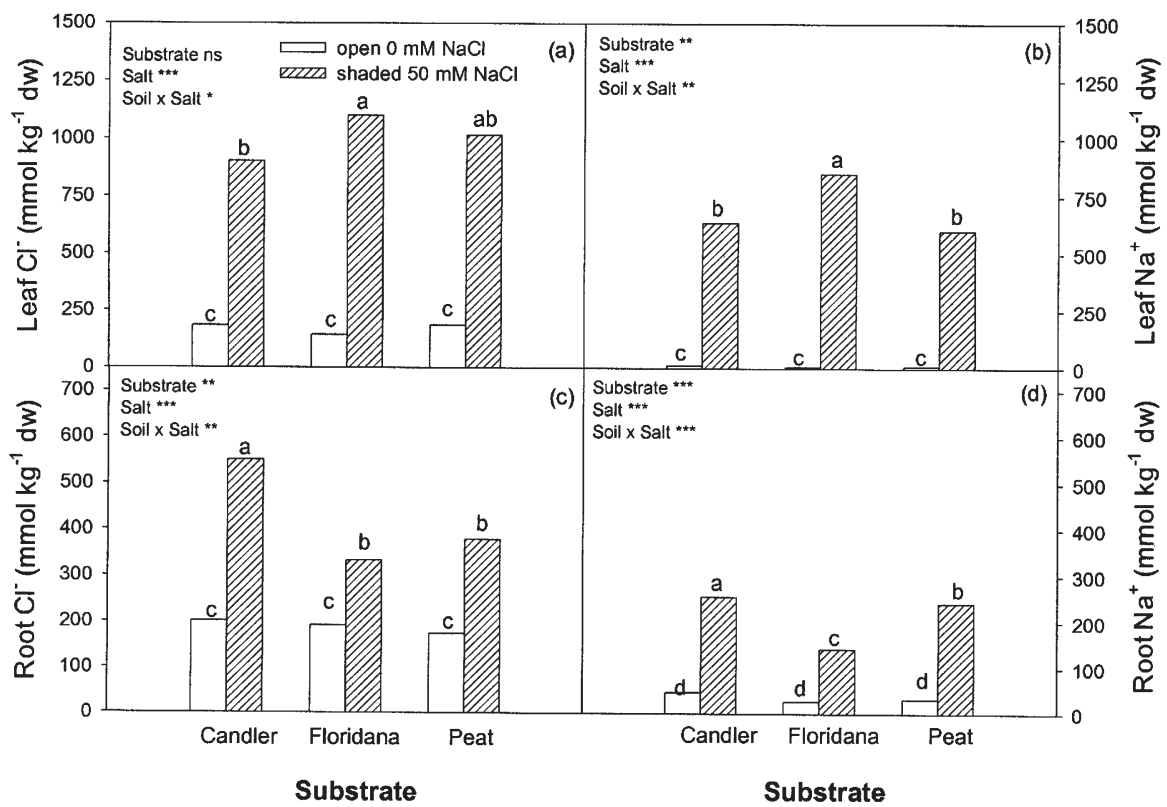

Fig. 2. Effects of growth substrate (Candler sand, Floridana soil, or soilless peat) and salt treatment (control $=0 \mathrm{NaCl}$, open bars or salt $=50 \mathrm{mM} \mathrm{NaCl}$, shaded bars) on mean $(\mathrm{n}=6)$ leaf $\mathrm{Cl}^{-}(\mathbf{A})$, leaf $\mathrm{Na}^{+}(\mathbf{B})$, root $\mathrm{Cl}^{-}(\mathbf{C})$, root $\mathrm{Na}^{+}(\mathbf{D})$ concentrations of Carrizo citrange seedlings. Ns, *******Nonsignificant or significant differences at $P<0.05,0.01$, or 0.001 , respectively, for the main effects and two-way interaction of substrate $\times$ salt treatments. Different lower case letters within each figure indicate significant differences at $P<0.05$ among substrate $\times$ salt treatments.

ment decreased leaf $\mathrm{Ca}^{2+}$ and increased $\mathrm{K}^{+}$ concentration regardless of substrate type because there were no significant interactions between substrate and salinity. Leaf $\mathrm{Mg}^{2+}$ and phosphorus concentration were unaffected by the salt treatment. Leaf $\mathrm{N}$ con- centrations of nonsalinized control leaves averaged $3087 \mathrm{mmol} \cdot \mathrm{kg}^{-1} \mathrm{dr}$ wt $(=4.3 \%$ dr wt). Leaf nitrogen was unaffected by substrate, but salinity reduced average leaf nitrogen to $2382 \mathrm{mmol} \cdot \mathrm{kg}^{-1} \mathrm{dr}$ wt (= $3.3 \%)$. 
Table 2. Effects of growth substrate (Candler sand, Floridana soil, soilless peat) and salt treatment (control $=$ no $\mathrm{NaCl}$ or salt $=50 \mathrm{mM} \mathrm{NaCl})$ on mean $(\mathrm{n}=6)$ leaf and root $\mathrm{Ca}^{2+}, \mathrm{K}^{+}, \mathrm{Mg}^{2+}$, phosphorus $(\mathrm{P})$, and nitrogen $(\mathrm{N})$ concentrations $\left(\mathrm{mmol} \cdot \mathrm{kg}^{-1} \mathrm{dr} \mathrm{wt}\right)$ of Carrizo citrange seedlings.

\begin{tabular}{|c|c|c|c|c|c|c|}
\hline \multirow[b]{2}{*}{ Substrate } & \multirow[b]{2}{*}{ Salt treatment } & \multicolumn{5}{|c|}{ Leaf } \\
\hline & & $\overline{\mathrm{Ca}^{2+}}$ & $\mathrm{K}^{+}$ & $\mathrm{Mg}^{2+}$ & $\mathrm{P}$ & $\mathrm{N}$ \\
\hline \multirow[t]{2}{*}{ Candler } & Control & $699 \mathrm{~A}^{\mathrm{z}}$ & $686 \mathrm{~B}$ & $123 \mathrm{~B}$ & $81 \mathrm{~A}$ & 3,150 \\
\hline & Salt & 616 & 737 & 119 & 71 & 2,421 \\
\hline \multirow[t]{2}{*}{ Floridana } & Control & $666 \mathrm{~B}$ & $767 \mathrm{~A}$ & $136 \mathrm{~B}$ & $65 \mathrm{~B}$ & 3,114 \\
\hline & Salt & 544 & 829 & 128 & 65 & 2,218 \\
\hline \multirow[t]{2}{*}{ Soilless peat } & Control & $626 \mathrm{~B}$ & $701 \mathrm{~B}$ & $169 \mathrm{~A}$ & $68 \mathrm{AB}$ & 2,997 \\
\hline & Salt & 549 & 775 & 160 & 68 & 2,506 \\
\hline Substrate & & $* * \mathrm{y}$ & ** & $* * *$ & * & NS \\
\hline Salt & & $* * *$ & $* *$ & NS & NS & $* * *$ \\
\hline \multirow[t]{3}{*}{ Substrate $\times$ salt } & & NS & NS & NS & NS & NS \\
\hline & & \multicolumn{5}{|c|}{ Root } \\
\hline & & $\mathrm{Ca}^{2+}$ & $\mathrm{K}^{+}$ & $\mathrm{Mg}^{2+}$ & $\mathrm{P}$ & $\mathrm{N}$ \\
\hline \multirow[t]{2}{*}{ Candler } & Control & $262 \mathrm{~B}$ & $583 \mathrm{~A}$ & $169 \mathrm{~A}$ & $155 \mathrm{a}$ & 1,612 \\
\hline & Salt & 162 & 468 & 156 & $90 \mathrm{bc}$ & 1,605 \\
\hline \multirow[t]{2}{*}{ Floridana } & Control & $165 \mathrm{C}$ & $512 \mathrm{~B}$ & $128 \mathrm{C}$ & $71 \mathrm{~cd}$ & 1,640 \\
\hline & Salt & 130 & 317 & 78 & $52 \mathrm{~d}$ & 1,403 \\
\hline \multirow[t]{2}{*}{ Soilless peat } & Control & $269 \mathrm{~A}$ & $507 \mathrm{~B}$ & $140 \mathrm{~B}$ & $129 \mathrm{a}$ & 1,571 \\
\hline & Salt & 215 & 417 & 115 & $103 \mathrm{~b}$ & 1,599 \\
\hline Substrate & & $* * * \mathrm{y}$ & ** & $* * *$ & $* * *$ & NS \\
\hline Salt & & $* * *$ & $* * *$ & $* * *$ & $* * *$ & NS \\
\hline Substrate $\times$ salt & & NS & NS & NS & $*$ & NS \\
\hline
\end{tabular}

${ }^{\mathrm{z}}$ Different upper case letters within a column indicate significant differences at $P<0.05$ between substrates. Substrate $\times$ salt means within a column followed by different lower case letters are significantly different at $P<0.05$.

${ }_{\mathrm{NS}}, * * *, * * *$ Nonsignificant or significant differences at $P<0.05,0.01$, or 0.001 , respectively, for the main effects and two-way interactions between substrate $\times$ salt treatments.
Root $\mathrm{Ca}^{2+}$ concentration was lowest in Floridana soil and highest in roots from soilless peat (Table 2). Root $\mathrm{Mg}^{2+}$ concentration was also lowest in Floridana soil but highest in Candler sand in which root $\mathrm{K}^{+}$ concentration was also highest. In the control treatment, root phosphorus concentration was lowest in seedlings from Floridana soil. Salt treatment decreased root $\mathrm{Ca}^{2+}, \mathrm{K}^{+}$, and $\mathrm{Mg}^{2+}$ concentration in all substrates. Salinity also decreased root phosphorus concentration in seedlings from the soilless peat and Candler sand but not significantly so in the already lowest phosphorus in seedlings from Floridana soil. Root nitrogen concentrations varied from 1403 to $1640 \mathrm{mmol} \cdot \mathrm{kg}^{-1} \mathrm{dr} \mathrm{wt}$ $(2.0 \%$ to $2.3 \% \mathrm{dr} w \mathrm{w})$ and were unaffected by substrate or salinity.

Water relations. In the nonsaline control treatment, predawn $\Psi_{\mathrm{w}}$ was lower in seedlings from Floridana and Candler soil than those from peat, but $\Psi_{\pi}, \Psi_{\mathrm{p}}$, and midday
RWC were unaffected by substrate (Table $3)$. The salt treatment reduced $\Psi_{w}$ and $\Psi_{\pi}$ in all three substrates and these reductions were greater in seedlings from Floridana and soilless peat than for those from Candler soil. Salinity increased $\Psi_{\mathrm{p}}$ in seedling grown in Floridana soils and soilless peat but not in Candler sand. Leaf RWC was unaffected by salt treatment.

Leaf gas exchange and chlorophyll a fluorescence parameters. Leaves from seedlings in soilless peat had highest $\mathrm{A}_{\mathrm{CO} 2}$ and WUE in both control and salt treatments (Table 4). Salt treatment reduced $\mathrm{A}_{\mathrm{CO} 2}, \mathrm{~g}_{\mathrm{s}}$, WUE, and $\mathrm{E}_{\text {leaf }}$ relative to control leaves in all three substrates. Internal concentration of $\mathrm{CO}_{2}\left(\mathrm{C}_{\mathrm{i}}\right)$ varied from 321 to $348 \mu \mathrm{mol} \cdot \mathrm{mol}^{-1}$ and was unaffected by substrate type or salinity (data not shown). Leaves from nonsalinized seedlings grown in soilless peat had higher steady-state fluorescence yield (F) than those from Floridana soil but not differ-
Table 3. Effects of growth substrate (Candler sand, Floridana soil, soilless peat) and salt treatment (control $=$ no $\mathrm{NaCl}$ or salt $=50 \mathrm{mM} \mathrm{NaCl})$ on mean $(\mathrm{n}=6)$ leaf water potential $\left(\Psi_{\mathrm{w}}\right)$, leaf $\psi_{\mathrm{s}}\left(\Psi_{\pi}\right)$, leaf turgor potential $\left(\Psi_{\mathrm{P}}\right)$, and leaf relative water content (RWC) of Carrizo citrange seedlings.

\begin{tabular}{|c|c|c|c|c|c|}
\hline Substrate & Salt treatment & $\Psi_{\mathrm{w}}(\mathrm{MPa})$ & $\Psi_{\pi}(\mathrm{MPa})$ & $\Psi_{\mathrm{P}}(\mathrm{MPa})$ & RWC (\%) \\
\hline \multirow[t]{2}{*}{ Candler } & Control & $-0.44 b^{z}$ & $-2.57 \mathrm{a}$ & $2.13 \mathrm{bc}$ & 92.0 \\
\hline & Salt & $-0.64 \mathrm{c}$ & $-3.18 b$ & $2.54 \mathrm{~b}$ & 88.2 \\
\hline \multirow[t]{2}{*}{ Floridana } & Control & $-0.48 \mathrm{~b}$ & $-2.35 \mathrm{a}$ & $1.88 \mathrm{c}$ & 90.9 \\
\hline & Salt & $-0.72 \mathrm{~d}$ & $-3.74 c$ & $3.02 \mathrm{a}$ & 91.2 \\
\hline \multirow[t]{2}{*}{ Soilless peat } & Control & $-0.34 \mathrm{a}$ & $-2.44 \mathrm{a}$ & $2.10 \mathrm{c}$ & 92.2 \\
\hline & Salt & $-0.70 \mathrm{~cd}$ & $-3.68 \mathrm{c}$ & $2.98 \mathrm{a}$ & 84.3 \\
\hline Substrate & & $* * y$ & NS & NS & NS \\
\hline Salt & & $* * *$ & $* * *$ & $* * *$ & NS \\
\hline Substrate $\times$ salt & & $* *$ & $*$ & $*$ & NS \\
\hline
\end{tabular}

${ }^{\mathrm{z}}$ Substrate $\times$ salt means within a column followed by different lower case letter are significantly different at $P<0.05$.

${ }_{\mathrm{NS}}, * * * * * *$ Nonsignificant or significant differences at $P<0.05,0.01$, or 0.001 , respectively, for the main effects and two-way interactions between substrate $\times$ salt treatments. ent from those in Candler sand. Salt treatment increased $F_{o}, F$, and $F_{m}^{\prime}$ in leaves from seedlings in all three substrates. Photosytem II $F_{v} / F_{m}$ and $Y$ varied between 0.79 to 0.81 and 0.58 to 0.71 , respectively, but there were no effects of substrate type or salinity on these parameters (data not shown).

Electrical conductivity and $\mathrm{Cl}^{-}$concentration in the drainage solution. In the salt treatment, $\mathrm{EC}$ and $\mathrm{Cl}^{-}$concentration in the leached drainage solution was highest from Floridana soil (Fig. 3), whereas there were no significant differences between $\mathrm{EC}$ and $\mathrm{Cl}^{-}$in the leachate from Candler sand and soilless peat. In the nonsaline control treatment, there was no effect of substrate on the low EC and $\mathrm{Cl}^{-}$concentrations in the leachate.

\section{Discussion}

Under salinity stress, leaf $\mathrm{Cl}^{-}$concentrations were higher than leaf $\mathrm{Na}^{+}$supporting the well-known idea that Carrizo citrange is considered a $\mathrm{Cl}^{-}$accumulator but also a good $\mathrm{Na}^{+}$excluder (Levy and Syvertsen, 2004; Storey and Walker, 1999). Salinity had a negative effect on leaf growth in all three substrates because seedlings in the Candler sand grew the most leaf dry weight, whereas seedlings in Floridana soil grew the least. So, leaf growth was negatively related to leaf $\mathrm{Cl}^{-}$ because seedlings in the Candler sand had the lowest leaf $\mathrm{Cl}^{-}$, whereas seedlings in Floridana soil had the highest leaf $\mathrm{Cl}^{-}$. Based on leaf growth and $\mathrm{Cl}^{-}$rankings, the salinity tolerance of seedlings grown in Candler sand was highest and that of seedlings grown in Floridana soil was lowest. These data, therefore, did not support our original hypothesis that responses to salinity would be least in seedlings grown in the soilless peat mix.

Although substrates with high nutrient availability can support greater vegetative growth than low nutrient substrates (Fochesato et al., 2007), the higher waterholding capacity and CEC of the soilless peat mix did not affect whole plant growth in the wellwatered and fertilized nonsalinized control seedlings. It was possible that the frequent watering and fertilization every other day minimized any substrate differences in available water or nutrients. Leaf $\mathrm{Ca}^{2+}, \mathrm{K}^{+}$, phosphorus, and $\mathrm{Mg}^{2+}$ concentrations were within optimum range and leaf nitrogen was above the optimum range for bearing citrus (Embleton et al., 1973) in all three substrates reflecting the fact that seedlings were well-fertilized. Although leaf nitrogen was unaffected by substrate, other leaf mineral concentrations were affected by substrate type because leaf $\mathrm{Ca}^{2+}$ and phosphorus concentrations were highest in Candler, $\mathrm{K}^{+}$concentration was highest in Floridana soil, and $\mathrm{Mg}^{2+}$ concentration was highest in soilless peat. Thus, different leaf mineral concentrations among the seedlings from the three substrates could have played a role in their salt tolerance.

In citrus, negative effects of salinity have been attributed primarily to $\mathrm{Cl}^{-}$but also to $\mathrm{Na}^{+}$accumulation (Storey and Walker, 
Table 4. Effects of growth substrate (Candler sand, Floridana soil, soilless peat) and salt treatment (control $=$ no $\mathrm{NaCl}$ or salt $=50 \mathrm{mM} \mathrm{NaCl})$ on mean $(\mathrm{n}=6)$ net assimilation of $\mathrm{CO}_{2}\left(\mathrm{~A}_{\mathrm{CO} 2}\right)$, stomatal conductance $\left(\mathrm{g}_{\mathrm{s}}\right)$, photosynthetic water use efficiency $\left(\mathrm{WUE}=\mathrm{A}_{\mathrm{CO} 2} \mathrm{E}_{\mathrm{lf}}^{-1}\right)$, leaf transpiration $\left(\mathrm{E}_{\text {leaf }}\right)$, minimal fluorescence of dark-adapted leaves $\left(\mathrm{F}_{\mathrm{o}}\right)$, steady-state fluorescence yield $(\mathrm{F})$, and maximal $\left(\mathrm{F}_{\mathrm{m}}^{\prime}\right)$ of Carrizo citrange seedlings.

\begin{tabular}{llccccccc}
\hline Substrate & $\begin{array}{c}\text { Salt } \\
\text { treatment }\end{array}$ & $\begin{array}{c}\mathrm{A}_{\mathrm{CO} 2} \\
\left(\mu \mathrm{mol} \cdot \mathrm{m}^{-2} \cdot \mathrm{s}^{-1}\right)\end{array}$ & $\begin{array}{c}\mathrm{g}_{\mathrm{s}} \\
\left(\mathrm{mol} \cdot \mathrm{m}^{-2} \cdot \mathrm{s}^{-1}\right)\end{array}$ & $\begin{array}{c}\mathrm{WUE} \\
\left(\mu \mathrm{mol} \cdot \mathrm{mmol}^{-1}\right)\end{array}$ & $\begin{array}{c}\mathrm{E}_{\text {leaf }} \\
\left(\mathrm{mol} \cdot \mathrm{m}^{-2} \cdot \mathrm{h}^{-1}\right)\end{array}$ & $\mathrm{F}_{\mathrm{o}}$ & $\mathrm{F}$ & $\mathrm{F}_{\mathrm{m}}^{\prime}$ \\
\hline Candler & Control & $10.77 \mathrm{~B}^{\mathrm{z}}$ & 0.372 & $1.58 \mathrm{~B}$ & 4.41 & 141 & $141 \mathrm{AB}$ & 413 \\
& Salt & 6.63 & 0.249 & 1.23 & 3.43 & 156 & 155 & 453 \\
Floridana & Control & $9.73 \mathrm{~B}$ & 0.325 & $1.45 \mathrm{~B}$ & 4.29 & 147 & $134 \mathrm{~B}$ & 336 \\
& Salt & 7.11 & 0.293 & 1.23 & 3.86 & 163 & 147 & 513 \\
Soilless peat & Control & $13.61 \mathrm{~A}$ & 0.357 & $1.99 \mathrm{~A}$ & 4.47 & 148 & $150 \mathrm{~A}$ & 445 \\
& Salt & 7.58 & 0.243 & 1.51 & 4.03 & 152 & 161 & 471 \\
Substrate & & $* \mathrm{y}$ & $\mathrm{NS}$ & $*$ & $\mathrm{NS}$ & $\mathrm{NS}$ & $*$ & $\mathrm{NS}$ \\
Salt & & $* * *$ & $* *$ & $*$ & $* * *$ & $* *$ & $* *$ & $*$ \\
Substrate $\times$ salt & $\mathrm{NS}$ & $\mathrm{NS}$ & $\mathrm{NS}$ & $\mathrm{NS}$ & $\mathrm{NS}$ & $\mathrm{NS}$ & $\mathrm{NS}$ \\
\hline
\end{tabular}

${ }^{\mathrm{z}}$ Different upper case letters within a column indicate significant differences at $P<0.05$ between substrates.

$\mathrm{y}_{\mathrm{NS}}, * * * * * *$ Nonsignificant or significant differences at $P<0.05,0.01$, or 0.001 , respectively, for the main effects and two-way interactions between substrate $\times$ salt treatments.

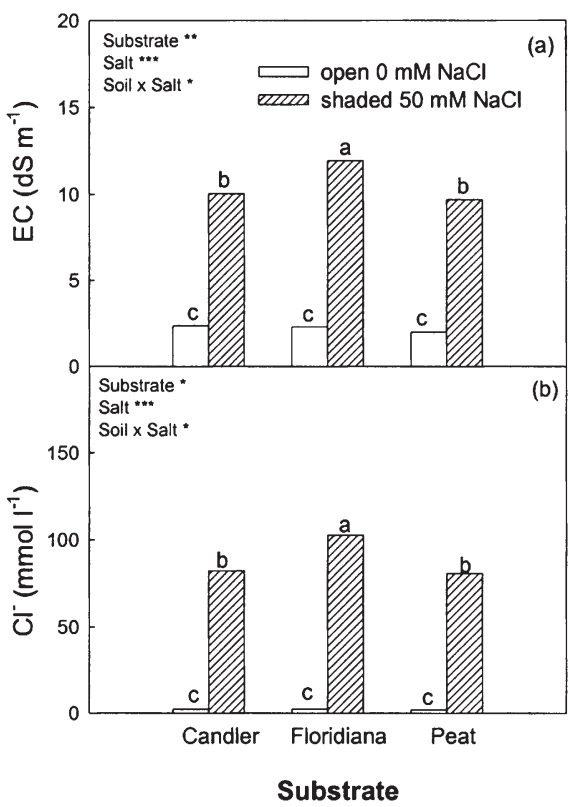

Fig. 3. Effects of growth substrate (Candler sand, Floridana soil, or soilless peat) and salt treatment (control $=0 \mathrm{NaCl}$, open bars or salt $=50$ $\mathrm{mM} \mathrm{NaCl}$, shaded bars) on mean $(\mathrm{n}=6)$ electrical conductivity $(\mathrm{EC} ; \mathbf{A})$ and $\mathrm{Cl}^{-}$concentration (B) in the drainage solution from Carrizo citrange seedlings. $*, * *, * * *$ Significant differences at $P<0.05,0.01$, or 0.001 , respectively, for the main effects and two-way interaction of substrate $\times$ salt treatments. Different lower case letters within each figure indicate significant differences at $P<0.05$ among substrate $\times$ salt treatments.

1987), but the severity of the effect of $\mathrm{Cl}^{-}$ accumulation on growth can also depend on the quantities of other nutrient ions in leaves and their interactions with salt ions (Bañuls et al., 1997). In our experiment, the higher leaf $\mathrm{Ca}^{2+}$ concentration in seedlings from Candler soil relative to leaf $\mathrm{Ca}^{2+}$ in soilless peat and Floridana soil could have diminished the negative effect of $\mathrm{Cl}^{-}$toxicity. Calcium has an intrinsic role in displacing $\mathrm{Na}^{+}$(Tattini and Traversi, 2009) and in improving growth of salinized citrus (RomeroAranda, et al., 1998) in which high leaf $\mathrm{Ca}^{2+}$ concentration ameliorated salt-induced leaf abscission and maintained membrane permeability (Bolat et al., 2006). Salinized Floridana seedlings also had the low values of $\mathrm{Mg}^{2+}$ and lowest phosphorus, which could have also contributed to their lowest salt tolerance. Salinity stress may increase plant phosphorus requirement to continue normal function (Awad et al., 1990) and the maintenance of leaf $\mathrm{Mg}^{2+}$ also might be especially important under salinity stress because $\mathrm{Mg}^{2+}$ is a cofactor of tonoplast ATPase (Donovan et al., 1997) and contributes to protein translation in the presence of high $\mathrm{Na}^{+}$(Marschner, 1995).

In previous studies with Carrizo citrange seedlings, physiological mechanisms responsible for $\mathrm{Cl}^{-}$uptake and transport have been linked to plant water use (Moya et al., 2003). A reduction of leaf $\mathrm{Cl}^{-}$can occur when the $\mathrm{Sh} / \mathrm{Rt}$ ratio is decreased by removing leaves and when leaf transpiration is decreased by root pruning (Moya et al., 1999) or by increasing atmospheric $\mathrm{CO}_{2}$ concentration (García-Sánchez et al., 2006). Here, however, leaf transpiration rates of salinized plants were unaffected by substrate (Table 4) so variations in water use could not have caused the high leaf $\mathrm{Cl}^{-}$concentrations in leaves from Floridana soil and low leaf $\mathrm{Cl}^{-}$ from Candler sand. The high leaf $\mathrm{Cl}^{-}$and $\mathrm{Na}^{+}$ concentrations in Floridana seedlings could have been attributable in part to higher levels of salt ions in the soil solution than those growing in Candler sand and soilless peat, supported by the high $\mathrm{EC}$ and $\mathrm{Cl}^{-}$concentration from salinized Floridana soil. The high clay content $(30 \%)$ in Floridana soil could have reduced the leaching fraction and increased the salt ion accumulation (see Fig. 3). Substrate type also influenced $\mathrm{Cl}^{-}$and $\mathrm{Na}^{+}$ distribution within seedlings because the highest root $\mathrm{Cl}^{-}$and $\mathrm{Na}^{+}$concentrations occurred in salinized seedlings from Candler sand while they maintained the highest leaf dry weight and lowest leaf $\mathrm{Cl}$ concentrations. Thus, growing Carrizo seedlings in Candler sand increased the ability of roots to accumulate salt ions avoiding their accumulation in leaves and allowing greater growth under salt stress. We did not evaluate root morphology, but it is possible that substrate-induced differences in root characteristics affected $\mathrm{Na}^{+}$and $\mathrm{Cl}^{-}$distribution by changes in $\mathrm{Na}^{+}$ and $\mathrm{Cl}^{-}$uptake and transport (Storey, 1995). When grown in aerated solution culture, rates of net $\mathrm{Na}^{+}$and $\mathrm{Cl}^{-}$uptake and transport were two- to eightfold higher than ion uptake by roots in sand culture. Clearly, roots grow and behave differently in different growth media.

In salinized citrus, decreases in $\mathrm{A}_{\mathrm{CO} 2}$ are a consequence of high leaf $\mathrm{Cl}^{-}$concentration because increasing leaf $\mathrm{Cl}^{-}$concentration progressively decreases $\mathrm{A}_{\mathrm{CO} 2}$ (Bañuls and Primo-Millo, 1992; García-Sánchez et al., 2002). Despite the higher leaf $\mathrm{Cl}^{-}$concentration in seedlings from Floridana soil, however, salinity-induced reductions in $\mathrm{A}_{\mathrm{CO} 2}, \mathrm{~g}_{\mathrm{s}}$, and $\mathrm{E}_{\text {leaf }}$ were similar for seedlings in all three substrates. At least under these conditions, therefore, leaf gas exchange was not a good indicator of growth and leaf $\mathrm{Cl}^{-}$ accumulation under salinity stress. This underscores the potential problem of describing relative salinity tolerance based solely on leaf gas exchange responses. The high leaf $\mathrm{K}^{+}$ concentration in Floridana-grown seedlings and the high leaf $\mathrm{Mg}^{2+}$ in peat-grown could have mitigated the negative leaf $\mathrm{Cl}^{-}$effects on leaf gas exchange (Cakmak, 2005). Salinity-induced reductions in $\mathrm{A}_{\mathrm{CO} 2}$ were not accompanied by any decrease in $\mathrm{C}_{\mathrm{i}}$ implying that reductions in $\mathrm{A}_{\mathrm{CO} 2}$ were the result of internal limitations (biochemical) rather stomatal limitations (García-Sánchez and Syvertsen, 2006). Despite the lack of salinity effects on $\mathrm{F}_{\mathrm{v}} / \mathrm{F}_{\mathrm{m}}$ and $\mathrm{Y}$, the increase in $\mathrm{F}_{\mathrm{o}}$ by the salt treatment supported the idea that decreased $\mathrm{A}_{\mathrm{CO} 2}$ was related to biophysical damage of photosystem II (PSII; Paranychianakis and Chartzoulakis, 2005). An increase of $F_{o}$ can be interpreted as a reduction of the rate constant of energy trapping by PSII centers resulting from a physical dissociation of the light harvesting complex in the PSII core (Havaux and Lannoye, 1983).

Although all seedlings were wellwatered, seedlings in soilless peat had higher predawn leaf water potentials reflecting the higher available water content of soilless peat than of the two soil types. However, substrate type had no effect on leaf turgor or RWC. Salinity reduced both $\Psi_{\mathrm{w}}$ and $\Psi_{\pi}$ such that leaf turgor was increased in seedlings grown in Floridana soils and soilless peat. As was shown previously (García-Sánchez and Syvertsen, 2006; Melgar et al., 2008), salinity-induced reductions in growth and net gas exchange were not the result of loss of turgor, but more likely the result of toxic ion accumulation in leaves.

In summary, based on the rankings of leaf growth and leaf $\mathrm{Cl}^{-}$in well-irrigated salinized Carrizo seedlings, those grown in Candler soil had the highest salinity tolerance, whereas those grown in Floridana soil had the lowest salt tolerance. This could have been related to the high clay content in the Floridana soil resulting in higher salt stress than in the other substrates. The high leaf $\mathrm{Ca}^{2+}$ concentration in seedlings from Candler 
sand could have mitigated the negative effects of $\mathrm{Cl}^{-}$and $\mathrm{Na}^{+}$toxicity. Substrate type also changed plant allocation patterns of $\mathrm{Cl}^{-}$ and $\mathrm{Na}^{+}$under salinity stress because seedlings grown in Candler sand accumulated high salt concentrations in roots while limiting salt ion transport to shoots. Comparative studies of crop responses to salinity and relative salt tolerance should consider the potential contributions of growth substrate.

\section{Literature Cited}

Awad, A.S., D.G. Edwards, and L.C. Campbell. 1990. Phosphorus enhancement of salt tolerance of tomato. Crop Sci. 30:123-128.

Bañuls, J. and E. Primo-Millo. 1992. Effects of chloride and sodium on gas exchange parameters and water relations of citrus plants. Physiol. Plant. 86:115-123.

Bañuls, J. and E. Primo-Millo. 1995. Effects of salinity on some citrus scion-rootstock combinations. Ann. Bot. (Lond.) 76:97-102.

Bañuls, J., M.D. Serna, F. Legaz, M. Talon, and E. Primo-Millo. 1997. Growth and gas exchange parameters and water relations of citrus plants stressed with different salts. J. Plant Physiol. 150:194-199.

Bolat, I., C. Kaya, A. Almaca, and S. Timucin. 2006. Calcium sulfate improves salinity tolerance in rootstocks of plum. J. Plant Nutr. 29:553-564

Boman, B.J. 2005. Salinity effects on Florida grapefruit in the Indian River region. HortTechnology 15:89-95.

Cakmak, I. 2005. The role of potassium in alleviating detrimental effects of abiotic stresses in plants. J. Plant Nutr. Soil Sci. 168:521-530.

Donovan, L.A., J.H. Richards, and E.J. Shaber. 1997. Nutrient relations of the halophytic shrub, Sarcobatus vermiculatus, along a soil salinity gradient. Plant Soil 190:105-117.

Embleton, T.W., W.W. Jones, C.K. Labanauskas, and W. Reuther. 1973. Leaf analysis as a diagnostic tool and guide to fertilization. Citrus Ind. 3:183-210. Appendix, 448-495

Fochesato, M.L., P.V.D. De Souza, G. Fer, and H.S. Maciel. 2007. Vegetative growth of citrus rootstocks producing in distinct commercials substrates. Cienc. Rural 37:970-975.

Fostad, O. and P.A. Pedersen. 2000. Containergrown tree seedling responses to sodium chloride applications in different substrates. Environ. Pollut. 109:203-210.

García-Sánchez, F., J.L. Jifon, M. Carvajal, and J.P. Syvertsen. 2002. Gas exchange, chlorophyll and nutrient contents in relation to $\mathrm{Na}^{+}$and $\mathrm{Cl}^{-}$ accumulation in 'Sunburst' mandarin grafted on different rootstocks. Plant Sci. 162:705-712.

García-Sánchez, F., J.G. Perez-Perez, P. Botía, and V. Martínez. 2006. The response of young mandarin trees grown under saline conditions depends on the rootstock. Eur. J. Agron. 24:129-139.

García-Sánchez, F. and J.P. Syvertsen. 2006. Salinity tolerance of Cleopatra mandarin and Carrizo citrange rootstock seedlings is affected by $\mathrm{CO}_{2}$ enrichment during growth. J. Amer. Soc. Hort. Sci. 131:24-31.

García-Legaz, M.F., J.M. Ortiz, A. García-Lidón, and A. Cerdá. 1993. Effect of salinity on growth, ion content and $\mathrm{CO} 2$ assimilation rate in lemon varieties on different rootstocks. Physiol. Plant. 89:427-432.

Grieve, A.M., L.D. Prior, and K.B. Bevington. 2007. Long-term effects of saline irrigation water on growth, yield, and fruit quality of Valencia orange trees. Aust. J. Agr. Res. 58: 342-348.

Havaux, M. and R. Lannoye. 1983. Chlorophyll fluorescence induction-A sensitive indicator of water-stress in maize plants. Irrig. Sci. 4:147-151.

He, Z.L., G.V. Calvert, A.K. Alva, and Y.C. Li. 2000. Management of nutrients in citrus production systems in Florida: An overview. Soil Crop Sci. Soc. Fl. 59:2-10.

Hodges, A., D. Mulkey, E. Philippakos, and M. Sanford. 2001. Economic impact of the Florida apiculture industry. Amer. Bee J. 141:361363.

Jifon, J.L. and J.P. Syvertsen. 2003. Moderate shade can increase net gas exchange and reduce photoinhibition in citrus leaves. Tree Physiol. 23:119-127.

Levy, Y., J. Lifshitz, Y. De Malach, and Y. David. 1999. The response of several Citrus genotypes to high-salinity irrigation water. HortScience 34:878-881.

Levy, Y. and J.P. Syvertsen. 2004. Irrigation water quality and salinity effects in citrus trees. Hort. Rev. (Amer. Soc. Hort. Sci.) 30:37-82.

Li, H., J.P. Syvertsen, C.W. McCoy, R.J. Stuart, and A.W. Schumann. 2006. Water stress and root injury from simulated flooding and Diaprepes abbreviatus root weevil larval feeding in citrus. Soil Sci. 171:138-151.

Marschner, H. 1995. Mineral nutrition of higher plants. Academic Press, New York, NY.

Maxwell, K. and G.N. Johnson. 2000. Chlorophyll fluorescence-A practical guide. J. Expt. Bot. 51:659-668.

Melgar, J.C., J.P. Syvertsen, V. Martínez, and F. García-Sánchez. 2008. Leaf gas exchange, water relations, nutrient content and growth in citrus and olive seedlings under salinity. Biol. Plant. 52:385-390.

Morgan, J.M. 1984. Osmoregulation and water stress in higher plants. Annu. Rev. Plant Physiol. 35:299-319.

Moya, J.L., A. Gomez-Cadenas, E. Primo-Millo, and M. Talón. 2003. Chloride absorption in salt-sensitive Carrizo citrange and salt-tolerant Cleopatra mandarin citrus rootstocks is linked to water use. J. Expt. Bot. 54:825-833.
Moya, J.L., E. Primo-Millo, and M. Talón. 1999. Morphological factors determining salt tolerance in citrus seedlings: The shoot to root ratio modulates passive root uptake of chloride ions and their accumulation in leaves. Plant Cell Environ. 22:1425-1433.

Paranychianakis, N.V. and K.S. Chartzoulakis. 2005. Irrigation of Mediterranean crops with saline water: From physiology to management practices. Agr. Ecosyst. Environ. 106:171-187.

Pérez-Pérez, J.G., J.P. Syvertsen, P. Botia, and F. García-Sánchez. 2007. Leaf water relations and net gas exchange responses of salinized Carrizo citrange seedlings during drought stress and recovery. Ann. Bot. (Lond.) 100:335-345.

Prior, L.D., A.M. Grieve, K.B. Bevington, and P.G. Slavich. 2007. Long-term effects of saline irrigation water on Valencia orange trees: Relationships between growth and yield, and salt levels in soil and leaves. Aust. J. Agr. Res. 58:349-358.

Romero-Aranda, R., J.L. Moya, F.R. Tadeo, F. Legaz, E. Primo-Millo, and M. Talón. 1998. Physiological and anatomical disturbances induced by chloride salts in sensitive and tolerant citrus: Beneficial and detrimental effects of cations. Plant Cell Environ. 21:12431253.

Soil Conservation Service. 1990. Soil survey of Polk County, Florida. USDA, University of Florida, Gainesville, FL.

Storey, R. 1995. Salt tolerance, ion relations and the effect of root medium on the response of citrus to salinity. Aust. J. Plant Physiol. 22: 101-114.

Storey, R. and R.R. Walker. 1987. Some effects of root anatomy on $\mathrm{K}, \mathrm{Na}$ and $\mathrm{Cl}$ loading of citrus roots and leaves. J. Expt. Bot. 38:1769-1780.

Storey, R. and R.R. Walker. 1999. Citrus and salinity. Sci. Hort. 78:39-81.

Syvertsen, J.P. 1984. Light acclimation in citrus leaves. II. $\mathrm{CO}_{2}$ assimilation and light, water, and nitrogen use efficiency. J. Amer. Soc. Hort. Sci. 109:812-817.

Syvertsen, J.P., B. Boman, and D.P.H. Tucker. 1989. Salinity in Florida citrus production. Proc. Fla. State Hort. Soc. 102:61-64.

Tattini, M. and M.L. Traversi. 2009. On the mechanism of salt tolerance in olive (Olea europaea L.) under low- or high- $\mathrm{Ca}^{2+}$ supply. Environ. Exp. Bot. 65:72-81.

Villagra, P.E. and J.B. Cavagnaro. 2005. Effects of salinity on the establishment and early growth of Prosopis argentina and Prosopis alpataco seedlings in two contrasting soils: Implications for their ecological success. Austral Ecol. 30:325-335.

Yamada, M., H. Fujiyama, T. Endo, M.U. Rikimaru, Y. Sasaki, S. Yamamoto, T. Honna, and T. Yamamoto. 2007. Effect of K-type and Catype artificial zeolites applied to high sodic soil on the growth of plants different in salt tolerance. Soil Sci. Plant Nutr. 53:471-479. 